\title{
倒木を伴う急傾斜地崩壊災害の 3 次元個別要素法による数值シミュレーション NUMERICAL SIMULATION FOR LANDSLIDE WITH FALLEN TREES USING 3D DISTINCT ELEMENT METHOD
}

\author{
原田英治 ${ }^{1}$ ・後藤仁志 ${ }^{2}$ ・酒井哲郎 ${ }^{3}$ ・合田健 ${ }^{4}$ \\ Eiji HARADA, Hitoshi GOTOHT, Tetsuo SAKAI and Kenichi GOUDA \\ ${ }^{1}$ 正会員 工博 豊田工業高等専門学校助教授 環境都市工学科（广 471-8525 豊田市栄生町 2-1） \\ 2 正会員 工博 京都大学助教授 工学研究科都市環境工学専攻（T 615-8540 京都市西京区京都大学桂） \\ 3 フェロー 工博 京都大学教授 工学研究科都市環境工学専攻（７ 615-8540 京都市西京区京都大学桂） \\ 4学生会員 京都大学大学院修士課程＼cjkstart都市環境工学専攻（～６15-8540 京都市西京区京都大学桂）
}

\begin{abstract}
To reduce damages of recurrent disasters of landslide in moutainside towns, a constant awareness of the disaster prevention is important. A dynamic and visual representation of a disaster would play an effective role to explain a danger of a landslide disaster. In the present study, numerical simulation of a landslide was performed using the three-dimensional Distinct Element Method, and an eloquent performance of this kind of simulator was represented by showing various angle of snapshots. Especially, a landslide considered with fallen trees modeled by the passively-moving-solid model was simulated because a usual landslide disaster contains fallen trees, and the simulation result showed a good agreement with an actual landslide in a tendency of accumulation form.
\end{abstract}

Key Words : landslide disaster, fallen trees, passively moving solid model, 3D Distinct Element Method

\section{1. はじめに}

都市近郊斜面での急傾斜地崩壊による甚大な災害 は毎年報告されている．急傾斜地崩壊の主な素因は 台風等の継続的集中豪雨による地下水位上昇に伴う 地盤強度の減少であるが, 国道整備・高速道路・ダ 厶等の山間部への近年の建設域の拡大は, 地盤の不 安定性を誘発する原因となっており，人為開発に対 する適切な急傾斜地崩壊災害防止工の検討は被害抑 制には不可欠である. 同時に, 危険地域の設定，避 難体制の確立といったソフト面での災害回避の対応 策も重要であり, ハザードマップの作成や物理的根 拠に基づいて開発された数值シミュレーションによ る適切な被災域予測や住民に対する分かり易い土砂 災害の説明が求められている。

従来, 土石流等の流動土砂挙動予測には, 平面 2 次元漸変流としての運動方程式・連続式およびクー ロン摩擦に代表される抵抗則を連立して解く Euler
型の手法が実スケール問題に対して頻繁に用いられ てきた（例えば, 高橋ら ${ }^{1)}$ )。 ところで, 近年の急速 なパーソナルコンピュータの演算処理能力向上の恩 恵から, Lagrange 型のシミュレーション手法の一つ である 3 次元個別要素法型の粒状体モデルによる数 十メートルオーダーの大規模計算が並列計算技術と 併せて実施されている $\left(\right.$ 後藤ら $\left.{ }^{2}\right)$ ），このような個別 要素法型のモデルによる実スケール規模を対象とし た数值シミュレーション結果のアニメーションは, 被災状況を静的ではなく動的に認識し易く, 常日頃 から土砂災害危険区域の住民が防災の意識を持ち続 けるための支援ツールとして有効であると考える.

これまで, 3 次元個別要素法べースの粒状体モデ ルによる急傾斜地崩壊を対象とした数值シミュレー

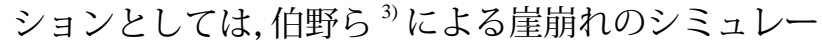
ション等があるものの, 崩壊斜面表面に繁茂してい る樹木を考慮した数值シミュレーションを対象とし た研究例は見当たらない. 急傾斜地崩壊後の映像に 


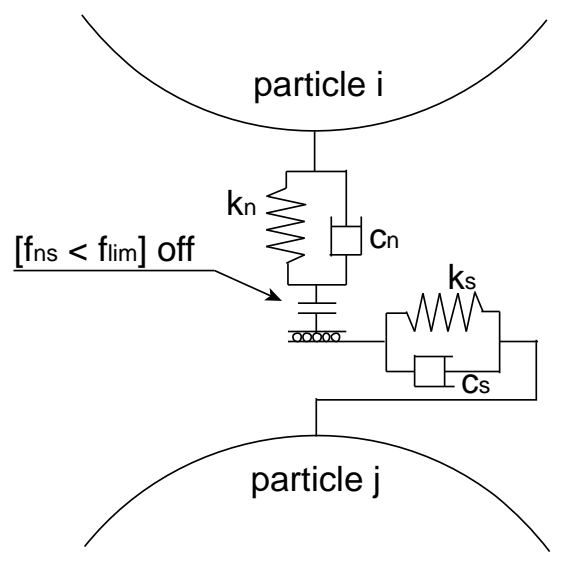

図-1 バネ-ダッシュポット系

は崩壊した土砂・石礫のみならず，流木群の散乱し た状況が確認される事実からも, 斜面に繁茂して いた樹木を含めた斜面崩壊挙動の評価は必要であろ う。また，樹木を含めた崩壊予測は，実際の災害の リアリティーを追求することに繋がるため, 住民に 対して分かり易い説明資料の提供に貢献すると期待 される.

ここでは，防災意識向上支援ツール開発への取り 組みの一環として, 3 次元個別要素法型の粒状体モ デルによる, 流木を含む急傾斜地崩壊挙動を予測す るための数值シミュレーションコードの開発に取り 組んだ成果を示す.

\section{2. シミュレーションの概要}

\section{(1) 3 次元個別要素法}

個々の砂粒子レベルまで数值シミュレーションの 解像度を上げて追跡することは不可能であるので, ここでは計算対象領域の崩壊土を直径 1 メートルの 代表球形要素の塊に分割し, それらの挙動を個別要 素法型の粒状体モデル ${ }^{4)}$ を用いて Lagrange 的に評 価した. 個々の代表球形要素の運動は, 隣接要素と の接触力に起因する並進および回転の運動方程式

$$
\begin{gathered}
\frac{d^{2} \boldsymbol{r}_{i}}{d t^{2}}=\frac{\boldsymbol{F}_{i}}{M_{i}}+\boldsymbol{g} \\
\frac{d^{2} \boldsymbol{\phi}}{d t^{2}}=\frac{\boldsymbol{T}_{i}}{I_{i}} \\
M_{i}=\sigma_{i} \frac{\pi}{6} d_{i}^{3} ; I_{i}=\frac{\sigma_{i} \pi d_{i}^{5}}{60}
\end{gathered}
$$

によって記述される.ここに, $\boldsymbol{r}_{i}=\left(x_{i}, y_{i}, z_{i}\right), \phi_{i}=\left(\phi_{x i}\right.$, $\left.\phi_{y i}, \phi_{z i}\right)$ : グローバル座標系 $(x, y, z)$ 上での要素 $i$ の位 置と回転角, $\boldsymbol{F}_{i}=\left(F_{x i}, F_{y i}, F_{z i}\right)$ : グローバル座標系上 での要素間接触力, $M_{i}$ : 要素 $i$ の質量, $\boldsymbol{T}_{i}=\left(T_{x i}, T_{y i}\right.$, $\left.T_{z i}\right)$ : グローバル座標系上での要素間作用モーメン ト, $I_{i}$ : 要素 $i$ の慣性モーメント, $g$ : 重力加速度べ クトル, $\sigma$ : 要素 $i$ の要素比重, $d_{i}$ : 要素 $i$ の直径で

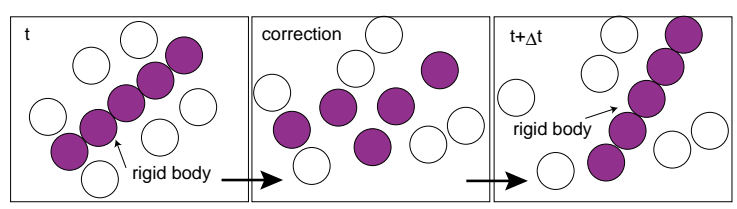

図-2 剛体モデル

ある.

要素間接触力の評価は, 接触点におけるローカル 座標系 $(\xi, \eta, \zeta)$ において, 2 要素間接平面の法線方 向および接平面内の 2 つの成分について, Voigt モ デル（バネ-ダッシュポット系；図 -1 参照）を配 置してモデル化される. バネおよびダッシュポット のモデル定数は，木山・藤村 ${ }^{5)}$ や重松ら ${ }^{6}$ と同様に Hertzの弾性接触理論に基づき決定したが，モデル 定数群の設定時に基準となるヤング係数 $E$ は, 本研 究で実施した計算領域程度の被災現場の写真 -1 を 参照しつつ崩壊土砂の堆積範囲を概ね再現するよう に $E=1.0 \times 10^{7} \mathrm{~Pa}$ とした. 土石流のように流動距離 が長く, 土砂礫と水が十分に混合された状態で, 平 衡流動区間が観測される場合には，平衡区間におけ る流動則等との比較からモデル定数の妥当性が検討 できるが，急傾斜地崩壊のように勾配急変部での現 象が対象である場合，流動区間が短く，十分に崩壊 土塊が混合していないため, 崩壊土塊の非均質性が 強い. しかも, 非定常性の強い場を取り扱うため平 衡流動則の再現性の観点からの設定は不都合であ る. そこで本研究では, 倒木を含む急傾斜地崩壊の 最終形状を概ね良好に再現するようにモデル定数を 設定した。

崩壊土要素間には、粘着力を模擬するため引つ張 りに対する抵抗力を持たせた. 引つ張り抵抗力は以 下の式で表現した.

$$
\begin{gathered}
\boldsymbol{F}_{i}=0 \text { when } f_{n s}<f_{\text {lim }} \\
f_{\text {lim }}=-d_{i} \cdot T_{m l} \cdot k_{n}
\end{gathered}
$$

ここに, $f_{\text {lim }}$ : 引つ張り抵抗力, $T_{m l}$ : 引つ張り抵抗力 を規定する係数 (本研究では $T_{m l}=0.01$ に設定した), $k_{n}$ : 法線方向のバネ定数, $f_{n s}$ : 法線方向のバネによ る力である.

\section{(2) 剛体モデル}

倒木は, 5 つの球形要素の中心が一直線上に並ぶ ように剛体連結して形成した.また，その挙動は， Koshizuka $ら^{7)}$ の Passively Moving Solid Model を準 用し, 剛体の重心回りの角運動量および並進運動量 を保存するように相対回転角および並進移動量を算 定し, 座標修正を施して剛体挙動させている. シミュ レーションでは, 最初に倒木構成要素間の連結関係 はないものとして, 全要素を 3 次元個別要素法で追 跡する. その結果, 倒木構成要素は初期の相対位置 

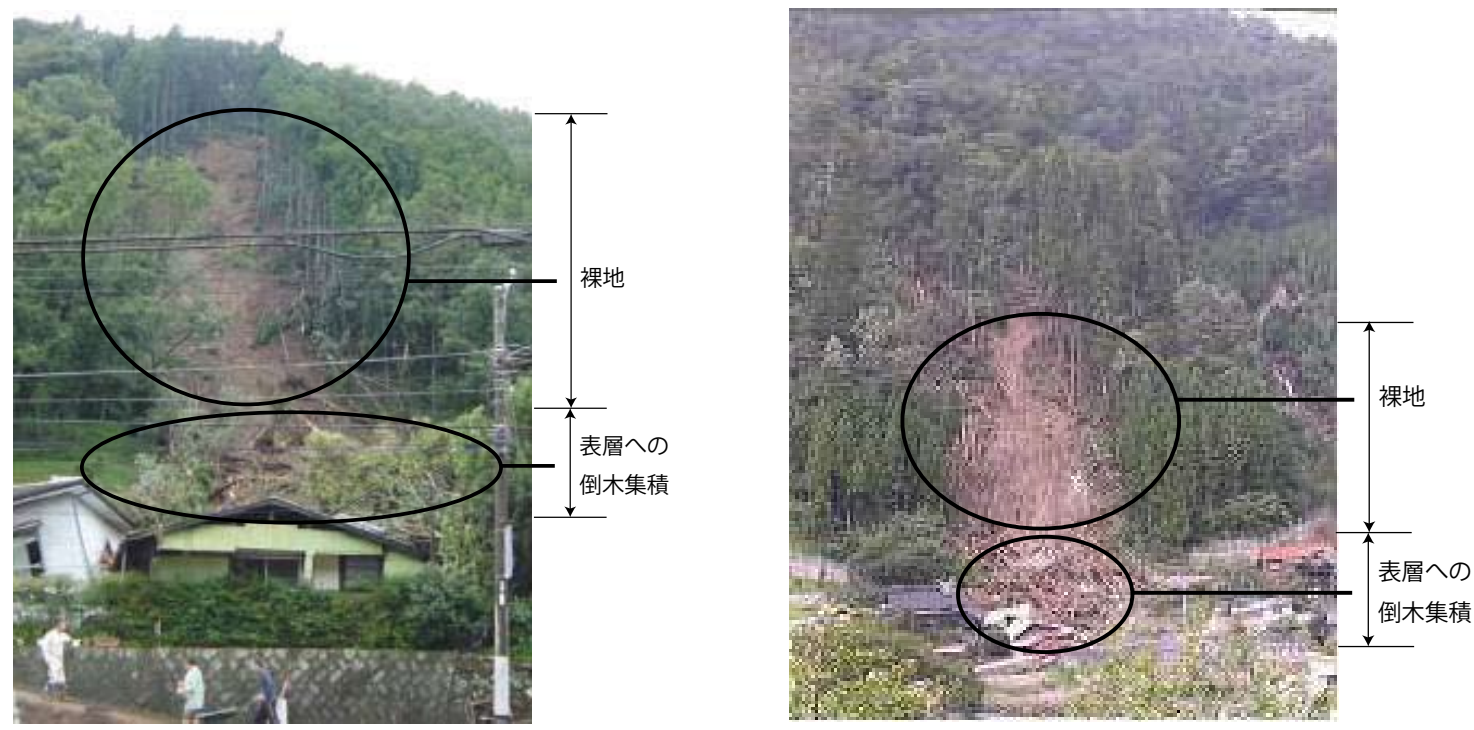

写真-1 静岡県伊豆市浜井場地区（左), 広島県山県郡筒賀村坂原地区（右）

$<$ 写真提供 : (社) 全国治水砂防協会 $>$

関係が崩れ変形するが，倒木構成要素間の初期の相 対位置を変化させないよう、直後に座標修正計算を 施す (図-2参照). 座標修正計算は以下の通りである. 先ず，倒木構成要素の時刻 $t+\Delta t$ での仮速度と仮座標 より重心座標 $\boldsymbol{r}_{g}$ と重心座標での並進速度べクトル $\boldsymbol{t}$, 重心回りでの角速度ベクトル $\boldsymbol{R}$ を算定する.

$$
\begin{gathered}
\boldsymbol{t}=\frac{1}{n} \sum_{i=1}^{n} \boldsymbol{u}_{i} \\
\boldsymbol{R}=I_{t}^{-1} \sum_{i=1}^{n} \boldsymbol{q}_{i} \times \boldsymbol{u}_{i} \\
\boldsymbol{q}_{i}=\boldsymbol{r}_{i}-\boldsymbol{r}_{g} \\
\boldsymbol{r}_{g}=\frac{1}{n} \sum_{i=1}^{n} \boldsymbol{r}_{i}
\end{gathered}
$$

ここに, $I_{t}$ : 倒木構成要素の重心回りの慣性テンソル, $n$ : 倒木構成要素数, $\boldsymbol{r}_{i}$ : 位置ベクトルである. 以上 を用いて, 倒木構成要素 $i$ の位置べクトルは, オイ ラー法によって時間積分され，

$$
\boldsymbol{r}_{i}=\boldsymbol{r}_{\text {pre } i}+\left(\boldsymbol{t}+\boldsymbol{q}_{i} \times \boldsymbol{R}\right) \Delta t
$$

と修正される.ここに, $\boldsymbol{r}_{\text {pre }}$ : 1 ステップ前の要素 $i$ の位置べクトルである．角速度 $\boldsymbol{R}$ が大きくなければ オイラー法によって倒木の姿勢は上手く追跡できる が, 他の要素から強い接触力が剛体構成要素に作用 すると, 角速度 $\boldsymbol{R}$ が大きくなり, 倒木構成要素の相 対位置に顕著なズレが現れ易くなる．そのため，回 転による変位は剛体姿勢の記述に頻用されるクオー タニオン（例えば, 越塚 $\left.{ }^{8}\right)$ を用いて以下のように 算定した．個々の倒木の重心 $\boldsymbol{r}_{g}$ を原点とする回転軸 $\boldsymbol{R} /|\boldsymbol{R}|$ 周りに回転角 $|\boldsymbol{R}| \Delta t$ ほど回転するクオータニオ ン $\boldsymbol{Q}$ とその共役クオータニオン $\boldsymbol{Q}^{*}$ および修正前の
座標のクオータニオン $\boldsymbol{Q}_{B}\left(0 ; \boldsymbol{q}_{i}\right)$ から修正後の座標の クォータニオン $\boldsymbol{Q}_{A}\left(0 ; \boldsymbol{q}_{i}\right)$ は,

$$
\boldsymbol{Q}(|\boldsymbol{R}| \Delta t ; \boldsymbol{R} /|\boldsymbol{R}|)=
$$$$
\cos \left(\frac{|\boldsymbol{R}| \Delta t}{2}\right)+\boldsymbol{A}^{\prime} \sin \left(\frac{|\boldsymbol{R}| \Delta t}{2}\right)
$$$$
\boldsymbol{A}^{\prime}=i^{\prime} \frac{R_{x}}{|\boldsymbol{R}|}+j^{\prime} \frac{R_{y}}{|\boldsymbol{R}|}+k^{\prime} \frac{R_{z}}{|\boldsymbol{R}|}
$$

$$
Q^{*}(|\boldsymbol{R}| \Delta t ; \boldsymbol{R} /|\boldsymbol{R}|)=
$$$$
\cos \left(\frac{|\boldsymbol{R}| \Delta t}{2}\right)-A^{\prime} \sin \left(\frac{|\boldsymbol{R}| \Delta t}{2}\right)
$$

$$
\begin{aligned}
& \boldsymbol{Q}_{A}\left(0 ; \boldsymbol{q}_{i}\right)= \\
& \boldsymbol{Q}^{*}(|\boldsymbol{R}| \Delta t ; \boldsymbol{R} /|\boldsymbol{R}|) \boldsymbol{Q}_{B}\left(0 ; \boldsymbol{q}_{i}\right) \boldsymbol{Q}(|\boldsymbol{R}| \Delta t ; \boldsymbol{R} /|\boldsymbol{R}|)
\end{aligned}
$$

となり, 樹木の各構成要素の位置 $\boldsymbol{r}_{i}$ は,

$$
\boldsymbol{r}_{i}=\boldsymbol{r}_{\text {pre } i}+\boldsymbol{t} \Delta t+\boldsymbol{q}_{i}
$$

と評価される.ここに $i^{\prime}, j^{\prime}, k^{\prime}$ : 虚数単位である.

\section{(3) 初期条件}

対象計算領域を図-3に示す。計算領域は直 径 $d=1.0 \mathrm{~m}$ の均一球形要素 77,635 個（移動要素 : 14,469 個, 固定要素：63,166 個）を用いて形成した. 移動要素は計算領域中程の $z=35.0 \mathrm{~m}-69.0 \mathrm{~m}$ の領域 （崩壊斜面）であり,その他の領域は固定要素である.

移動要素で構成された崩壊斜面には球形要素 5 つ を直連結し構成された総計 88 本の樹木を等間隔で 斜面土塊表層に埋め込むように配置した。

要素の比重は, 崩壊土および固定要素が $\sigma=2.65$ とし, 樹木については根部での土粒子との絡みを考 慮して, 図のように根部では $\sigma=2.65$, その他の 4 つの要素は $\sigma=0.9$ とした. 


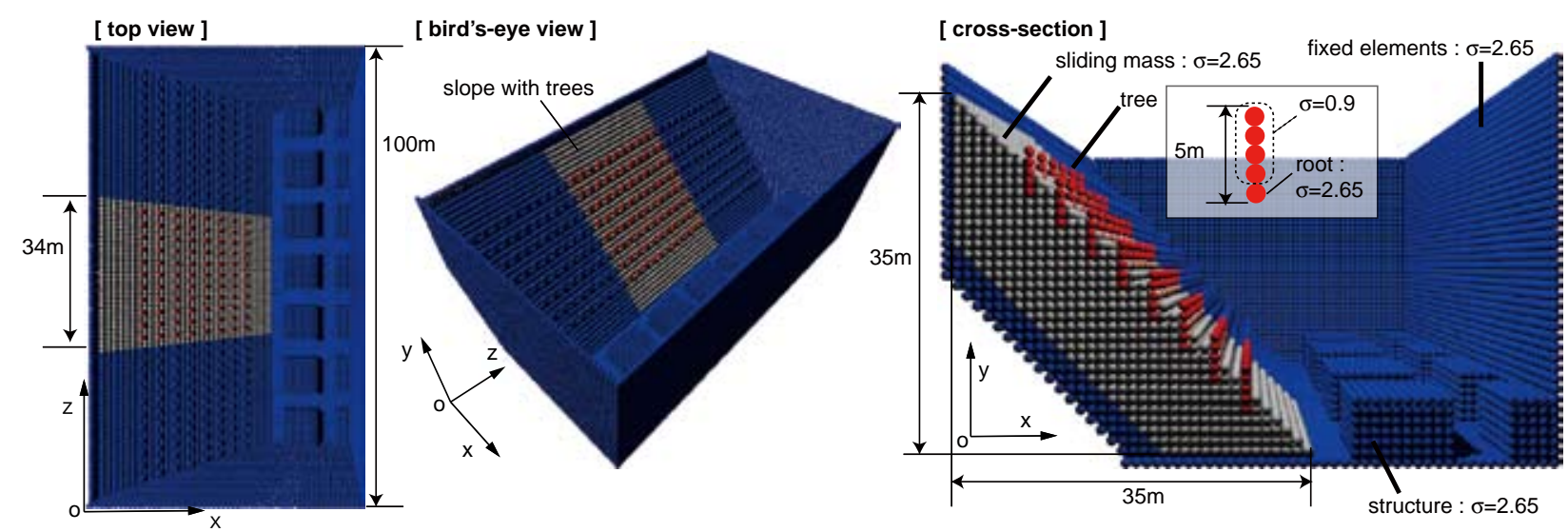

図-3 計算領域：上方図・鳥瞰図 - 横断面図

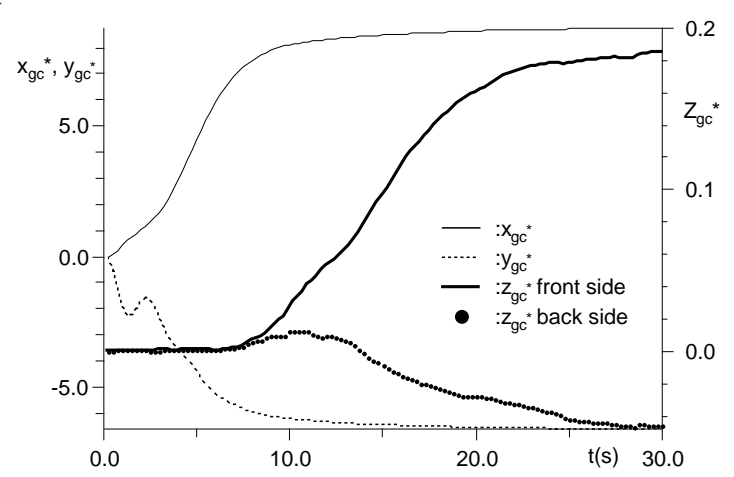

図-4 濃度重心時系列

一方，固定要素を用いて滑り面と構造物（家屋の モデル）を含む水平床を形成したが，構造物は $x \times$ $y \times z=10 \mathrm{~m} \times 6 \mathrm{~m} \times 10 \mathrm{~m}$ の直方体を等間隔に配置 した。 なお、固定境界面上の粗度は粒径程度である.

崩壊斜面構成要素には，計算開始と同時に瞬間的 に $x$ 軸方向に約 $1,500 \mathrm{~cm} / \mathrm{s}^{2}(\mathrm{Gal})$ の加速度を作用さ せ斜面崩壊のトリガーとした。初期の崩壊土塊要素 配列が symple cubic packing array（最疎充填）であ るため要素間の噛み合わせが緩く, 瞬間的な加速度 の作用でも斜面崩壊を引き起こすことができる.

\section{3. シミュレーション結果}

斜面崩壊過程の崩壊土塊の濃度重心の時系列を 図 -4 に示す. 奥行き（ $z$ 軸方向）については, $z \geqq$ $50.0 \mathrm{~m}$ の要素 $\left(z_{g c}{ }^{*}\right.$ back side $)$ と $z<50.0 \mathrm{~m}\left(z_{g c}{ }^{*}\right.$ front side）の要素に分けて濃度重心を示した. $x$ 軸 方向の濃度重心からおよそ時刻 $t=5.0-8.0 \mathrm{~s}$ に顕著な 崩壊土塊の $x$ 軸方向への伸びが示されている. また, それに伴う $y$ 軸方向の濃度重心の下降が示されてお り，急激な斜面崩壊の発生が窺える．奥行き（ $z$ 軸 方向）への崩壊土塊の拡がりについては, $x, y$ 軸 方向の濃度重心の変化率と比較して僅かではあるも のの, $x$ 軸方向への崩壊土塊の進行過程が鈍化する
につれて活発化し時刻 $t=30.0 \mathrm{~s}$ 付近で崩壊過程が収 束する様子が見て取れる.

瞬間像を図 -5 に示す。崩壊状況を空間的に認識 できるように上面図・正面図・横断面図 $(x-y$ 平面, $z=50.0 \mathrm{~m})$ を併示した. 崩壊開始後, 時刻 $t=4.0 \mathrm{~s}$ では, 崩壊土塊のフロントの前方 $(x$ 軸正方向 $)$ への伸び が示されている，正面図からは，崩壊土塊が背面 固定壁付近で斜面全域に渡って大きく沈下している 様子が樹木の初期位置からの相対変化より確認でき る. また, 横断面図からも固定背面付近での土塊の 顕著な沈下とそれに伴う前方 $(x$ 軸正方向 $)$ への土 塊の滑り状況が明瞭に理解できる.このような斜面 崩壊形態は室内実験 ${ }^{9}$ でも確認されており（図 -6 参 照), 本シミュレーションで与えた崩壊トリガーの妥 当性の一端を示していると考えらえる. また, 崩壊 土塊フロント部付近では, 固定床からの移動抵抗に よる崩壊土塊の僅かな隆起が見て取れる．樹木につ いてはこの時点では傾倒することなく崩壊土塊の運 動に連動して斜面を下降している. 時刻 $t=8.0 \mathrm{~s}$ では, 崩壊土塊のフロントの前方 $(x$ 軸正方向 $)$ への伸び が進行し, 一部のフロントの構造物への到達や構造 物間の路地への侵入が確認できる. 正面図からは崩 壊土塊と構造物の衝突による崩壊土塊要素の不規則 な流動の影響を受けて, 樹木が傾倒する様子が窥え る.この様子は, 横断面図からも見て取れるが，一 部の構造物に乗り上げる樹木や土塊内部での樹木の 様子等, 樹木傾倒状況を詳細に理解することができ る. また, 崩壊土塊の前方（ $x$ 軸正方向）への流動 が構造物によって遮蔽されるため, 斜面と構造物間 では層厚の継続した増加が確認できる. 時刻 $t=12.0 \mathrm{~s}$ になると, 樹木の殆どが傾倒しているのが 3 枚の図 から分かる. 上面図からは崩壊土塊の前方 $(x$ 軸正 方向）への進行とともに, 斜面と構造物間の路地に 扔いて奥行き方向（ $z$ 軸方向）への側方流動による 崩壊土塊の堆積域の拡大も見て取れる. 一方, 横断 面図からは, 斜面と構造物間の崩壊土塊の堆積層厚 

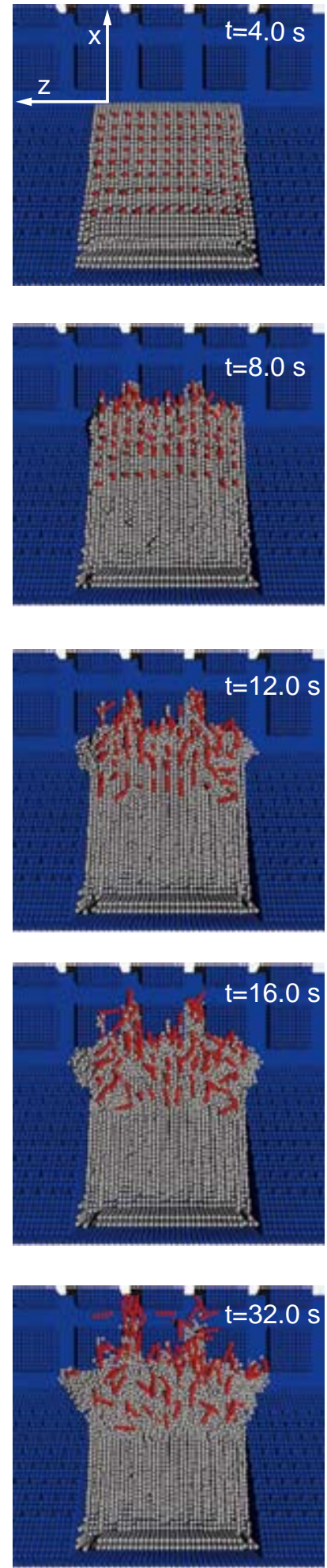

[ top view ]
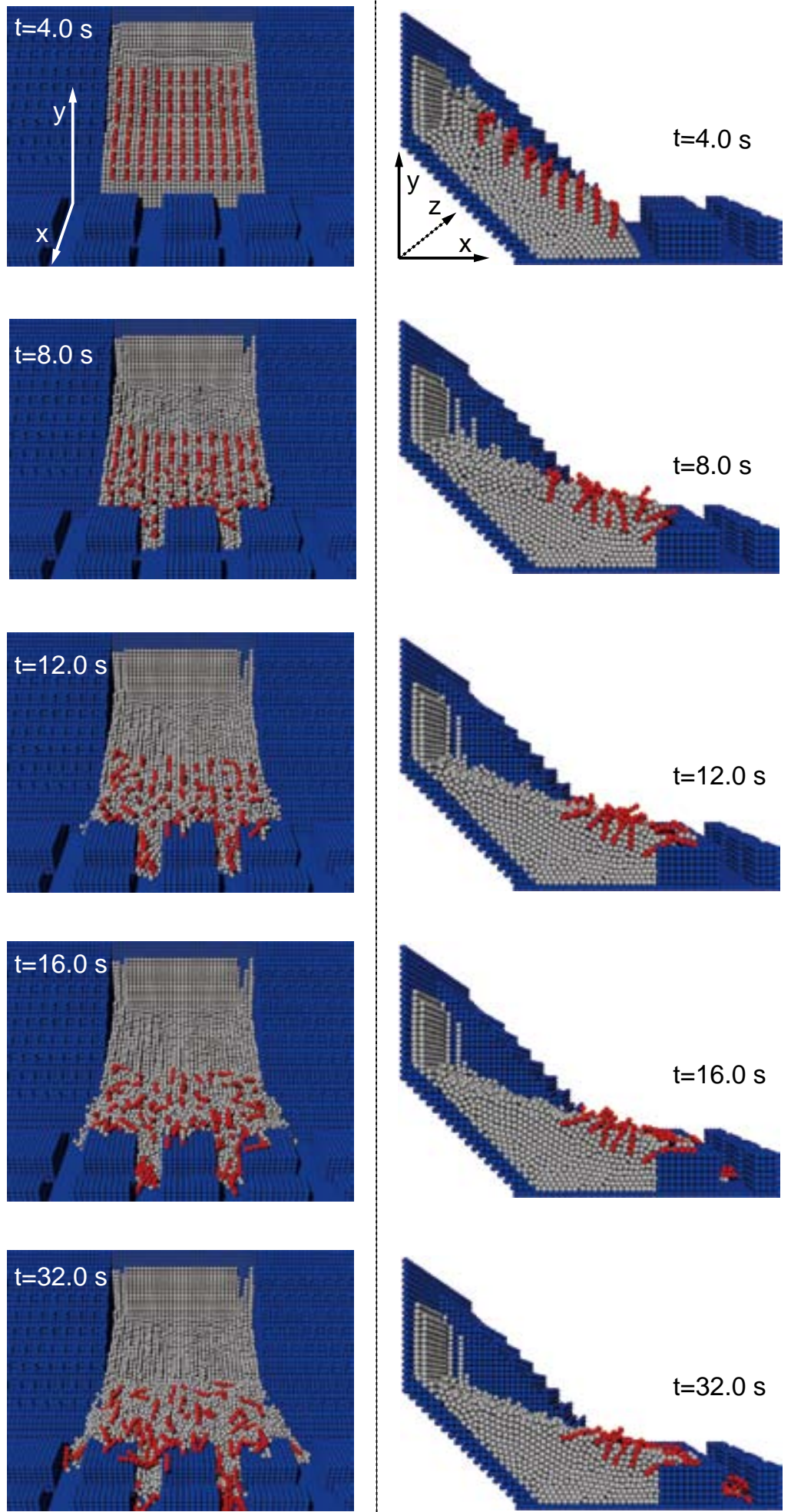

[ front view ]

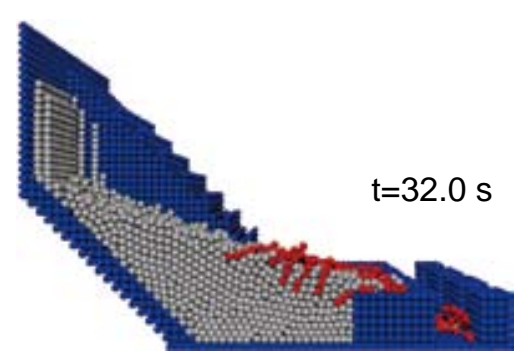

[ cross-section at $z=50.0 \mathrm{~m}$ ]

図-5 瞬間像：上面図 $\cdot$ 正面図 $\cdot$ 横断面図

の増加傾向が収束しつつある様子や樹木の傾倒が促 進されている状況が見て取れる. 時刻 $t=16.0 \mathrm{~s}$ では, 崩壊土塊の前方 $(x$ 軸正方向) への堆積域拡大はほ ぼ収束していることが図 -4 の時系列や時刻 $t=12.0 \mathrm{~s}$ の上面図との比較から分かる. 側方 $(z$ 軸方向 $)$ 一 は継続して, 僅かながら堆積域を拡大している様子
が窥える. 時刻 $t=32.0 \mathrm{~s}$ は本シミュレーションの最 終堆積形状を示す図である. 崩壊土塊が放射状に伸 びて堆積し, フロント前縁部に倒木集積している様 子が確認できる. この傾向は, 先に示した写真 -1の 被災状況傾向を良好に再現していることが分かる。

このように 3 次元個別要素法を基礎とした粒状体 


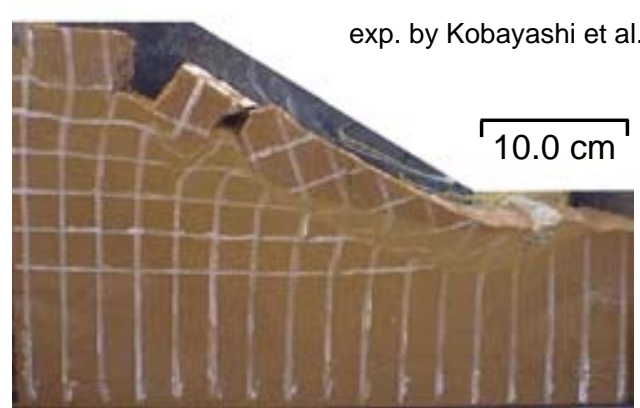

図-6 斜面崩壊実験画像

モデルを用いたシミュレーション結果は, 急傾斜地 崩壊過程を視覚的に分かり易く表示することが可能 であり，さらに様々な角度から被災状況にアプロー チすることが可能であるため，住民や施主に対する 土砂災害の説明に対して有効な手段になると期待さ れる.

\section{4. おわりに}

本研究では, 斜面の流動性崩壊災害を対象に, 3 次元個別要素法型の粒状体モデルを用いて検討し た. また，斜面に繁茂する樹木は剛体として取り扱 い, その挙動は 3 次元の剛体姿勢を追跡可能な移動 剛体モデルを導入して評価した.

今後は, 現地観測データとの比較から本シミュ レーションの再現性を詳細に確認するとともに, 樹 木の根による移動抵抗力や樹木の弾塑性挙動といっ たモデル化, 浸透流等, 今回のモデルで考慮されて いない箇所の検討を進めて, シミュレーションモデ ルの精度向上に努めたい. また, 崩壊土砂による家 屋崩壊過程をも含めたシミュレーションの実施を進 め, さらにイメージし易い、実現象に近い防災支援 ツールの開発を目指したい。
謝辞：本研究は, 文部科学省科学研究費 (若手研究 （B）,『固液混相流モデルによる急傾斜地液状化地滑 り災害の計算力学的研究』, 代表者：原田英治）の 補助を受けて行われた。ここに記して感謝の意を表 する.

\section{参考文献}

1) 高橋 保・中川 一・山路昭彦：土石流氾濫危険範 囲の指定法に関する研究, 京都大学防災研究所年報, 第 30 号 B-2, pp.611-626, 1987.

2）後藤仁志・五十里洋行 - 原田英治・酒井哲郎：大規 模土砂流動シミュレーションのための 3 次元並列型 数值移動床, 水工学論文集, 第 49 巻, pp.607-612, 2005.

3) 伯野元彦：破壊のシミュレーション - 拡張個別要素 法で破壊を追う -, 森北出版株式会社, 230p, 1997.

4）後藤仁志 - 原田英治 - 酒井哲郎 : 三次元個別要素法 による数值移動床の一般化, 水工学論文集, 第 46 巻, pp.613-618, 2002.

5) 木山英郎・藤山 尚：カンドルの離散剛要素法を用 いた岩質粒状体の重力流動の解析, 土木学会論文報 告集，第333号，pp.137-146，1983.

6) 重松孝昌 - 小田一紀・田野雅彦・廣瀬真由：個別要 素法による水中沈降粒子群の3 次元挙動に関する研 究, 海岸工学論文集, 第 47 巻, pp.996-1000, 2000.

7) Koshizuka, S., A. Nobe and Y. Oka : Numerical analysis of breaking waves using the moving particle semi implicit method, Int. J. Numer. Meth. Fluids, Vol. 26, pp. 751-769, 1988.

8) 越塚誠一: 計算力学レクチャーシリーズ 5 粒子法, 丸善株式会社, 144p, 2005.

9）小林 睦 - 廣岡明彦・永瀬英生・清水惠助・片山 亮・織掛晴弘：法先排水工ならびにジオテキスタイ ルによる補強工を施した盛土の降雨時安定性に関す る遠心模型実験, 土木構造・材料論文集 第 17 号, pp.97-104, 2001.

(2006.9.30 受付) 